\title{
Pathology and ultrastructure of an intranuclear bacilliform virus (IBV) infecting brown shrimp Crangon crangon (Decapoda: Crangonidae)
}

\author{
G. D. Stentiford*, K. Bateman, S. W. Feist \\ Centre for Environment, Fisheries and Aquaculture Science (CEFAS), Barrack Road, Weymouth, Dorset DT4 8UB, UK
}

\begin{abstract}
The brown shrimp Crangon crangon supports an important fishery in Europe (over $25000 \mathrm{t}$, valued at 80 million euros in 2000). Through the course of histopathological screening of crustaceans from the Clyde estuary, western Scotland, for the biological effect of contaminants, we have discovered a highly prevalent (up to $100 \%$ ) non-occluded intranuclear bacilliform virus (IBV) infection in the hepatopancreatic tubule epithelia and midgut epithelia of wild C. crangon. This is the first report of an IBV in this family. We have termed this virus Crangon crangon bacilliform virus (CcBV). Histological and ultrastructural observations suggest that this virus is similar to other IBVs previously described from crabs and penaeid shrimps. The nuclei of virus-infected epithelial cells contained an eosinophilic, hypertrophied viroplasm that marginalised the chromatin of the host nucleus. Infected cells were often separated from their neighbouring cells and their nuclei appeared apoptotic. In heavily infected shrimp, apoptotic cells were expelled into the lumen of the hepatopancreatic tubule or the midgut. Following this stage, some hepatopancreatic tubules became degenerate, with remnants of the basement membrane and myoepithelial lining remaining. Transmission electron microscopy of hypertrophic nuclei revealed the presence of rod-shaped and cylindrical, envelope-bound virions. These virions did not form arrays and were not embedded within occlusion bodies, but did appear to be partially occluded in an amorphous matrix that corresponded to a granular viroplasm. The ultrastructure, morphology and size of the nucleocapsid and the complete virion aligns the virus most closely to the IBVs previously reported from other decapod crustaceans. Due to the pathological manifestation of IBV infection in C. crangon, it appears likely that it can act as a population modulator, particularly at sites where infection prevalence is high, such as that observed in the Clyde estuary.
\end{abstract}

KEY WORDS: Bacilliform virus - Crangon crangon - Estuary · Hepatopancreas - Histopathology · IBV $\cdot$ Prevalence $\cdot$ Ultrastructure

\section{INTRODUCTION}

Since the discovery of the first crustacean virus in the crab Macropipus (= Liocarcinus) depurator during the 1960s (Vago 1966), there have now been over 50 viruses described from a diverse range of crustacean groups. Some of these are enveloped and nonenveloped cytoplasmic viruses that mainly infect portunid crabs (Johnson 1983), while rod-shaped nuclear viruses are the most common viral agents encountered in shrimp under aquaculture conditions (Johnson \&
Lightner 1988). With the expansion of the worldwide aquaculture industry for shrimp, it is now widely accepted that diseases caused by viruses are a major limiting factor in the economic production of this group (Flegel 1997, Aguirre Guzmán \& Ascencio Valle 2000). Furthermore, with the expected expansion of this industry, possibly using novel culture species, the discovery of new viral agents is likely. As such, it has been recommended that as much data as possible be collected of viral pathogens from wild decapod stocks (Johnson 1984, Bonami \& Lightner 1991, Vogt 1996). 
The Baculoviridae are a family of structurally and genetically complex viruses that to date have only been observed infecting arthropods. The family consists of 2 subgroups: the granulosis viruses (GVs) and the nucleopolyhedrosis viruses (NPVs), both of which form occlusion bodies within their infected host cells. A third group, previously associated with the baculoviruses, were the 'non-occluded baculoviruses' (NOBs) which do not form occlusion bodies but had virions which were morphologically similar. Due to a lack of biochemical, immunological and molecular data on the viruses that form this group, the NOBs are now unassigned by the International Committee on Taxonomy of Viruses (Murphy et al. 1995, Blissard et al. 1999). As such, viruses previously designated as NOBs have alternatively been referred to as intranuclear bacilliform viruses (IBVs) (Evans \& Edgerton 2002). In addition to the insects (Adams \& McClintock 1991, Tanada \& Hess 1991), a number of decapod crustaceans harbour NPV (Couch 1991) and IBV infections (Huger \& Krieg 1991). The IBVs show considerable morphological similarity to the true baculovirions, with cylindrical nucleocapsids, a subapical envelope expansion and a tail-like appendage arising from the nucleocapsid and reflexed within the expansion (Johnson \& Lightner 1988).

In addition to its importance as a key food-chain component (Berghan 1994, Walter \& Becker 1996, del Norte-Campos \& Temming 1998), brown shrimp Crangon crangon support an important fishery in Europe, particularly in the North Sea (over $25000 \mathrm{t}$, valued at 80 million euros in 2000; ICES 2001). Here, we provide the first description of an IBV infection in the hepatopancreatic tubule and midgut epithelia of wild C. crangon from the Clyde estuary, western Scotland. This is the first report of an IBV from the Crangonidae family. We have named this virus Crangon crangon bacilliform virus $(\mathrm{CcBV})$. Ultrastructural and pathological observations of $\mathrm{CCBV}$ suggest that this virus is similar to other IBVs described from crabs, freshwater crayfish and penaeid shrimps (Johnson \& Lightner 1988, Huger \& Krieg 1991). The histopathological manifestation of the CcBV infection is discussed in relation to its likely effect as a modulator of abundance and mortality in populations of C. crangon and to how such pathogens may take advantage of the weakened immune system caused by stressors such as pollution.

\section{MATERIALS AND METHODS}

Brown shrimp Crangon crangon were collected from the Erskine Bridge area of the Clyde estuary, western Scotland $\left(4^{\circ} 27.77^{\prime} \mathrm{W}, 55^{\circ} 55.21^{\prime} \mathrm{N}\right)$ in March and Octo- ber 2002 as part of an estuarine monitoring program to investigate the biological effects of contaminants. Shrimp were captured using a standard $2 \mathrm{~m}$ beam trawl fitted with a fine mesh cod-end, and were maintained in estuarine water for up to $1 \mathrm{~h}$ before processing for histology and electron microscopy.

Histology. Fifty brown shrimp from each sampling period were euthanised by direct injection with Davidson's seawater fixative (Hopwood 1996). Injected shrimp were immediately placed into the same solution for $24 \mathrm{~h}$ before transfer to $70 \%$ industrial methylated spirit for transport and storage. All samples were processed for histological examination within $7 \mathrm{~d}$ of collection, using standard protocols. For this, whole shrimp were sectioned longitudinally and the cut surface was placed outermost in the block for ease of sectioning. Whole shrimp sections were stained with haematoxylin and eosin (H\&E) and, selectively, resectioned material was stained with the FarleyFeulgen (FF) stain. Stained sections were examined by standard light microscopy and digital images were captured using the Lucia ${ }^{\mathrm{TM}}$ Screen Measurement System (Nikon).

Electron microscopy. Following evidence for the presence of a pathogen, the hepatopancreas was removed from 20 shrimp during the second sampling period (October) by severance of the abdomen, parting of the carapace longitudinally and removal of the whole hepatopancreas using fine forceps. Small blocks of tissue $\left(2 \mathrm{~mm}^{3}\right)$ were fixed in $2.5 \%$ glutaraldehyde in $0.1 \mathrm{M}$ sodium cacodylate buffer $(\mathrm{pH} 7.4)$ and $1.75 \%$ sodium chloride for $2 \mathrm{~h}$ at room temperature. Fixed tissue samples were rinsed in $0.1 \mathrm{M}$ sodium cacodylate buffer with $1.75 \%$ sodium chloride ( $\mathrm{pH} 7.4$ ) and postfixed for $1 \mathrm{~h}$ at $4^{\circ} \mathrm{C}$ in the same buffer. Specimens were washed in 3 changes of $0.1 \mathrm{M}$ sodium cacodylate buffer and stained en bloc in $0.5 \%$ aqueous uranyl acetate for $1 \mathrm{~h}$. Specimens were embedded in epoxy resin 812 (Agar Scientific pre-mix kit 812) following dehydration through a graded acetone series. Semithin $(1$ to $2 \mu \mathrm{m})$ sections were stained with Toluidine blue for viewing with a light microscope to identify suitable target areas. Ultrathin sections (70 to $90 \mathrm{~nm}$ ) of these areas mounted on uncoated copper grids and stained with uranyl acetate and Reynolds' lead citrate (Reynolds 1963) were examined using a JEOL JEM 1210 transmission electron microscope.

\section{RESULTS}

\section{Histology}

There were no obvious behavioural or pathological signs of disease among the shrimp collected in the 
March and October sampling periods from the Clyde estuary. Histological analysis of whole shrimp sections revealed a characteristic pathology in $100 \%$ of the shrimp collected during the March sampling period and $96 \%$ of those collected during the October sampling period. At low magnification, pathology consisted of a degeneration of hepatopancreatic tubules, causing a loss of histological structure in the organ (Fig. 1). At higher magnification, significant changes were seen in the differentiated epithelial cell types lining the hepatopancreatic tubules and of the epithelial cells lining the midgut. Hypertrophied and other aberrant nuclei either contained enlarged nucleoli (Fig. 2) or an amorphous eosinophilic matrix (Fig. 3). Nuclei that contained this matrix often had a disrupted chromatin profile with condensation of nuclear material along the inner nuclear membrane (Fig. 3). Strands of marginated chromatin often led to the appearance of discrete intra-nuclear compartmentalization (Fig. 4). Cells containing aberrant nuclei appeared singly or in clusters and the cytoplasm of intact affected cells appeared dense and basophilic, with an apparent loss of lipid storage inclusions (Fig. 5). Aberrant nuclei appeared to be confined to the storage $(\mathrm{R})$ and possibly fibrillar (F) cells of the hepatopancreatic tubules. In contrast, they were not observed either in the blister (B) cells or in the regenerating epithelial cells (E-cells) of the distal hepatopancreatic tubules. Mitotic figures were commonly seen within the E-cells. The percentage of hepatopancreatic epithelial cells containing aberrant nuclei in shrimps displaying this condition ranged from approximately 5 to $40 \%$.

The outer membrane of affected epithelial cells in the hepatopancreatic tubules and midgut was often separated from that of its neighboring cells (Fig. 5). These cells appeared to contain nuclei that were apoptotic (morphologically altered with condensed and fragmented chromatin profiles), and, in several cases, appeared to be in the process of expulsion into the lumen of the tubule or the midgut (Fig. 6). The cytoplasm of these cells often contained eosinophilic material in the perinuclear region. Sloughed epithelial cells containing aberrant nuclei could be seen within the lumen of degenerated tubules and in the midgut (Figs. 7 \& 8). Some tubules appeared necrotic, with degeneration of epithelial cells and only remnants of the basement membrane and myoepithelial lining remaining. Haemocytic encapsulation responses were not observed to engulf degenerate tubules.

\section{Ultrastructure}

Transmission electron micoscopy of aberrant hepatopancreatic epithelial cells revealed the presence of rod-shaped and cylindrical, envelope-bound particles within aberrant nuclei. These virions did not form arrays and some appeared to be partially embedded in an amorphous matrix which corresponded to a granular viroplasm (Fig. 9). The tri-laminar envelope that surrounded the nucleocapsid of many virions within the nucleus was expanded at one end to form a lateral protuberance. The opposite end of the virion appeared cylindrical with a closely opposed envelope (Fig. 10). In some cases, the lateral protuberance appeared to accommodate a fine tail-like structure that emerged from the proximal end of the nucleocapsid (not shown). The mean length of complete virions was $280.2 \pm$ $5.7 \mathrm{~nm}$, with a mean diameter of $71.8 \pm 1.3 \mathrm{~nm}$ and a mean envelope width of $5.3 \pm 0.1 \mathrm{~nm}$. The mean length of nucleocapsids was $215.2 \pm 5.03 \mathrm{~nm}$, with a mean diameter of $39.9 \pm 0.75 \mathrm{~nm}$.

Within the granular viroplasm, detached trilaminar membranes were observed, presumably the progenitor envelopes for the completed virion (Fig. 11). These membranes were often associated with discrete regions of dense viroplasm that appeared to be generating the nucleocapsid compartment of the virions (Fig. 12). Putative unbound nucleocapsids were observed in association with these dense regions of viroplasm in several aberrant nuclei. Cells sloughed to the lumen of the hepatopancreatic tubules contained nuclei with undefined borders. As such, although completed virions were not observed traversing the nuclear membrane, they were often observed in the cytoplasm of the infected cell (Fig. 13). In heavily infected cells, the outer nuclear envelope appeared dilated, and in numerous cases was expanded into a reticulum that extended into the cytoplasm immediately adjacent to the nucleus (Fig. 14). Often, this expansion was pronounced and appeared to form as either a massive proliferation of rough endoplasmic reticulum (RER) (Fig. 15), or a distinct membranous system that exhibited periodicity and appeared to generate vesicle-bound particles (Fig. 16). Cells containing such features were often rich in mitochondria (Fig. 17) and contained numerous lysosomal aggregations (Fig. 18). The combination of proliferated membranous material and pigmented lysosomal fractions corresponded to the eosinophilic peri-nuclear regions observed under light microscopy (Fig. 3).

\section{DISCUSSION}

This study has provided the first description of an intranuclear bacilliform virus (IBV) infecting the hepatopancreas and midgut epithelial cells of the European brown shrimp Crangon crangon from the Clyde estuary, western Scotland. We have termed this 


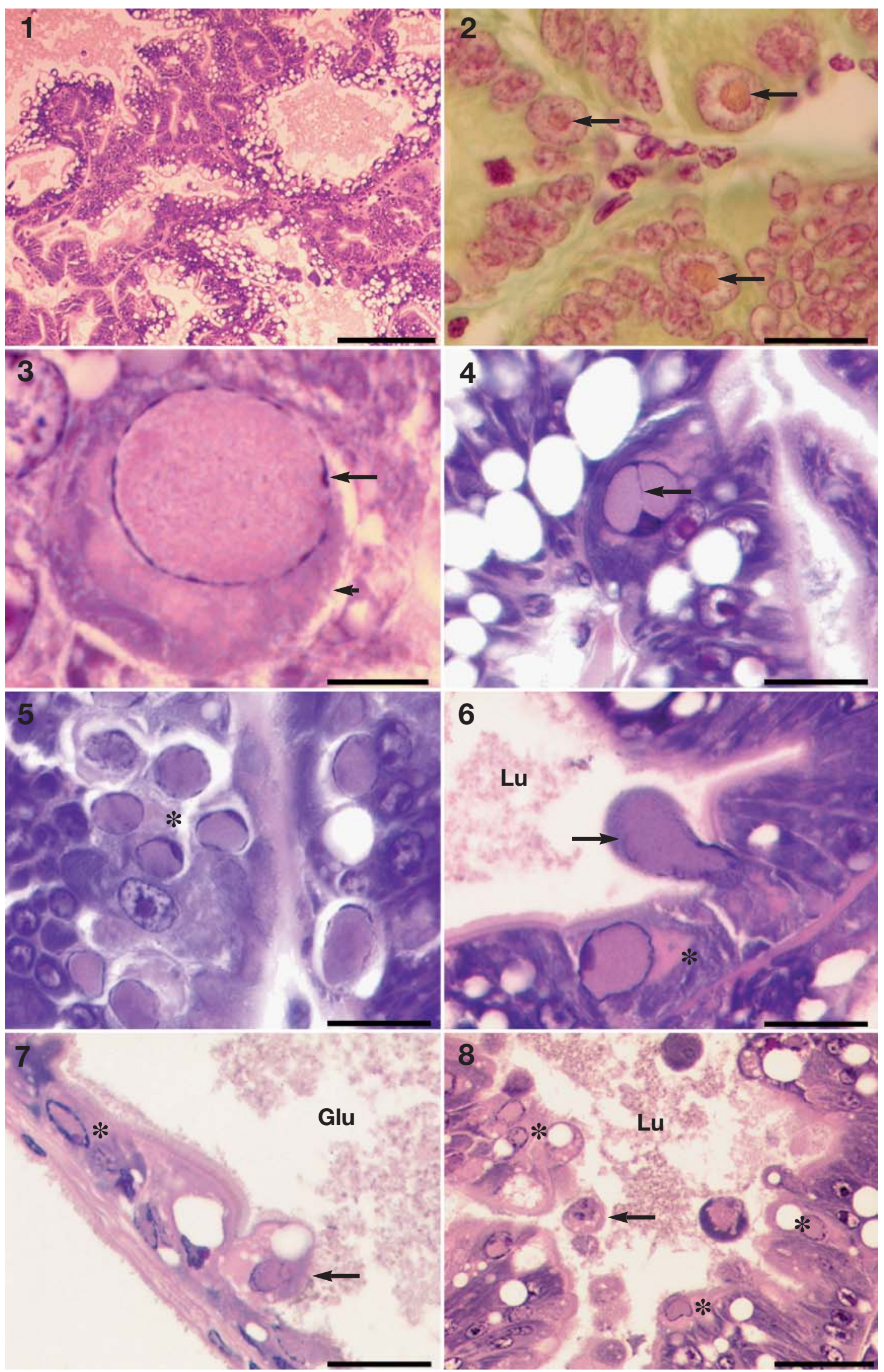


Figs. 1 to 8. Crangon crangon infected with C. crangon bacilliform virus (CcBV). Hepatopancreas of CcBV-infected brown shrimp. Fig. 1. Degeneration of the tubules and collecting ducts. Note the lack of hemocytic encapsulation response. H\&E stain, scale bar $\overline{=100} \mu \mathrm{m}$. Fig. 2. Tubule epithelial cells containing nuclei with enlarged nucleoli (arrows), possibly representing early infection. Feulgen stain, scale bar $=25 \mu \mathrm{m}$. Fig. 3. Single CcBV-infected cell with enlarged nucleus containing a fine granular matrix and marginal chromatin pattern (long arrow). Note the separation of the infected cell membrane from that of its uninfected neighbours (short arrow). H\&E stain, oil immersion, scale bar $=10 \mu \mathrm{m}$. Fig. 4. Margination of the chromatin has caused the formation of septa that has led to the appearance of discrete intra-nuclear compartmentalization (arrow). H\&E stain, scale bar $=25 \mu \mathrm{m}$. Fig. 5 . Cluster of CcBV-infected tubule epithelial cells displaying margination of chromatin and separation from their neighbours (asterisk). H\&E stain, scale bar $=25 \mu \mathrm{m}$. Fig. 6. CcBV-infected cells appeared to be expelled (arrow) to the tubule lumen (Lu), often leaving the basement membrane in direct contact with the tubule lumen. Adjacent cell also harbours CcBV infection (asterisk). H\&E stain, scale bar $=25 \mu \mathrm{m}$. Fig. 7. Midgut of CcBV-infected C. crangon. Infected cells were common within the epithelial lining of the gut (asterisk) and in a number of cases were apparently in the process of being expelled (arrow) into the gut lumen (Glu). H\&E stain, scale bar $=50 \mu \mathrm{m}$. Fig. 8. Hepatopancreatic collecting duct of CcBV-infected C. crangon. Infected epithelial cells (asterisks) can be seen bordering the lumen (Lu), while expelled infected cells (arrow) are present within the lumen. H\&E, scale bar $=50 \mu \mathrm{m}$

virus $C$. crangon bacilliform virus (CcBV). This is the first report of a virus from this family of shrimp and represents a significant addition to previous descriptions of IBV infections in decapods. That a high prevalence of virally infected shrimp were captured during the spring and autumn sampling periods suggests a lack of seasonality in infection prevalence. The ultrastructure of CcBV is characteristic of other intranuclear bacilliform viruses and as such, CcBV is most closely associated with this group (Johnson \& Lightner 1988). Description of this highly prevalent and apparently pathologic IBV in C. crangon is particularly important due to the relative lack of information on such infections in wild (non-cultured) crustacean species (Johnson 1984) and the importance of C. crangon as a fishery resource.

The lesions observed in the epithelium of the hepatopancreas and midgut of Crangon crangon are typical of those caused by bacilliform viruses described infecting other crustacean species (Johnson 1977, Sano et al. 1981, 1984, Pappalardo et al. 1986, Johnson \& Lightner 1988, Anderson \& Prior 1992, Groff et al. 1993, Edgerton et al. 1996, 2002). The pathological manifestation of $\mathrm{CcBV}$ was marked by eventual degeneration of the epithelial cells of the hepatopancreatic tubules and of the midgut. In severe cases, large areas of the hepatopancreas appeared necrotic, with loss of tubular structure and organ integrity. Although pathogenesis trials were not carried out, it is suggested that these features of CcBV may lead to dysfunction of the hepatopancreas and ultimately to death of the host, even though E-cells at the distal hepatopancreatic tubules are not apparently infected and continued to divide in infected shrimp. Apoptosis of hepatopancreatic tubule and midgut epithelial cells was a clear feature of $\mathrm{CcBV}$ infection. In fact, the mechanism for organ degeneration appeared to be driven by the relative levels of apoptosis within these organs. Apoptosis has been recognised as an innate response to virus infections in a number of disease models. At present, however, it is not entirely under- stood whether the apoptotic mechanism is initiated in an attempt to rid the host or cell of the virus, whether it is of benefit to the virus in terms of local and horizontal transmission, or whether it is a combination of both (Everett \& McFadden 1999). It is also possible that via the apoptotic mechanism, inflammation may be avoided (possibly explaining the lack of host response to CcBV-infected cells).

Prior to apoptotic destruction, electron microscopy revealed significant alterations to the cytoplasm of CcBV-infected cells. Infected cells were seen to contain large numbers of mitochondria, showed dilation of the outer nuclear membrane, and often developed an intricate membranous system reminiscent of the membranous labyrinth system described by Couch (1989) in Baculovirus penaei (BP)-infected penaeid shrimps. In the BP model, it is suggested that the labyrinth system may originate from 3 sources (the outer nuclear membrane, the Golgi and the endoplasmic reticulum) and that it can form concentric membrane masses or a highly organized labyrinthian structure. The role of the labyrinth is to provide structural precursors to the developing virions, and in the case of BP, for the polyhedrin-rich occlusion body (Couch 1989). Modification of cytoplasmic membrane structures has also been noted for other baculovirus infections of shrimps (Lightner et al. 1983) and for several viruses from other groups (Couch 1989). Whether the elaborate cytoplasmic membrane system noted in $\mathrm{CcBV}$ infection of $C$. crangon plays a similar role to that suggested for other virus models, or whether it simply represents a pathological symptom of viral infection, remains to be shown.

Although in several cases the hepatopancreas of CcBV-infected shrimp appeared to be in a state of severe degeneration, no haemocytic infiltration or encapsulation response (as noted by Johnson in 1984, Edgerton et al. 2000) was recorded. In addition to the possible effect of apoptosis in prevention of inflammatory reactions in CcBV-infected shrimp, the lack of host immune response to this pathology may also suggest that the immune system of shrimps captured from the 


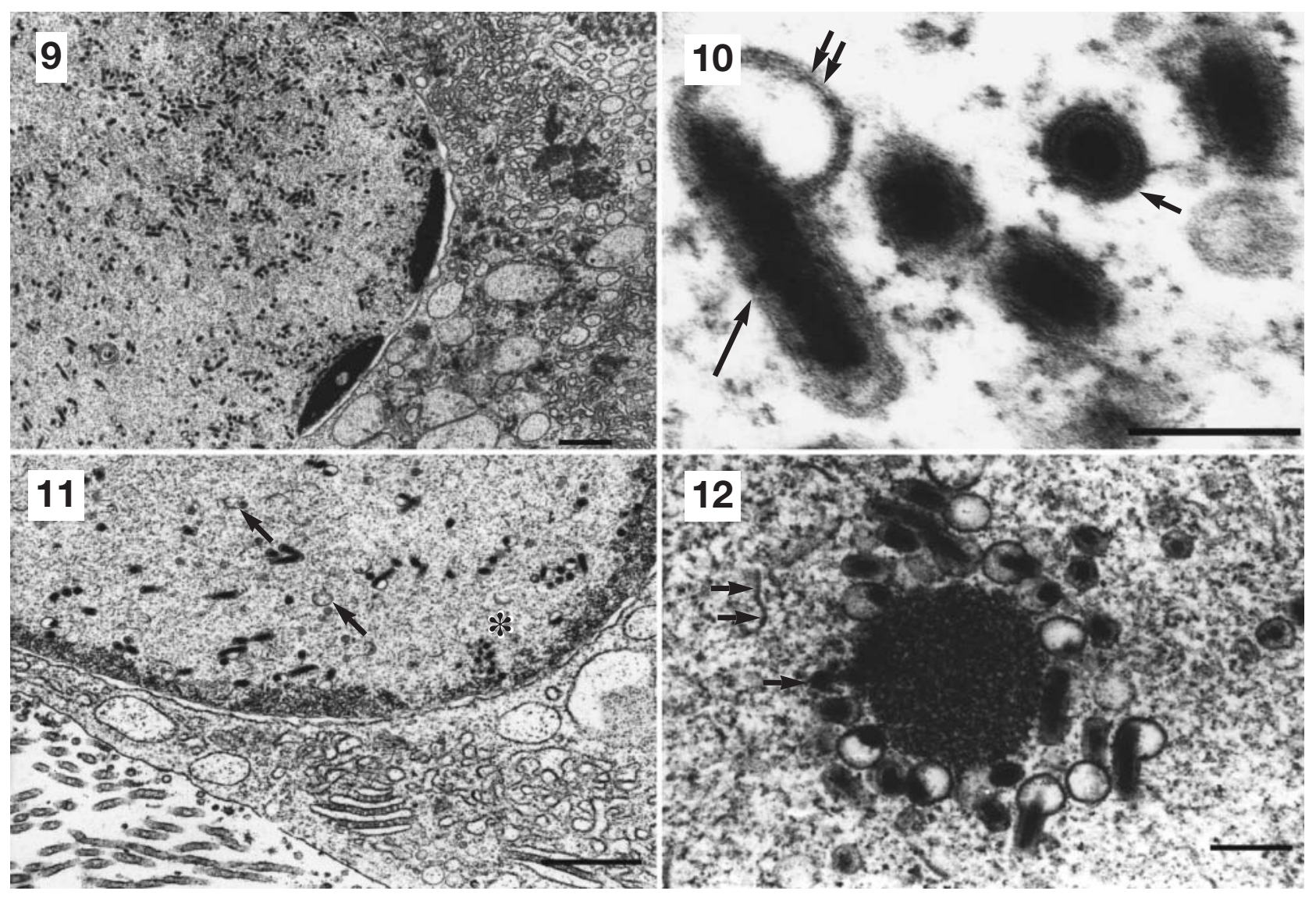

Figs. 9 to 12. Crangon crangon infected with C. crangon bacilliform virus (CcBV). Fig. 9. Nucleus from a CcBV-infected C. crangon cell containing rod-shaped bacilliform virions. Virions are present in transverse and longitudinal section with some appearing partially embedded in the fine granular matrix (viroplasm). Transfer electron microscope (TEM) image, scale bar $=1 \mu \mathrm{m}$. Fig. 10. Longitudinal (long arrow) and transverse (short arrow) section through bacilliform virions. The central core (nucleocapisid) is surrounded by a trilaminar membrane with a lateral expansion at one of its ends (double arrow). TEM image, scale bar $=250 \mathrm{~nm}$. Fig. 11. Nucleus from a CcBV-infected cell. Putative non-membrane bound electron-dense nucleocapsid cores can be observed at the periphery of the nucleus (asterisk), while free trilaminar membranes are found within the viroplasm (arrows). TEM image, scale bar $=1 \mu \mathrm{m}$. Fig. 12. Nucleus from a CcBV-infected cell showing bacilliform virions accumulating at the periphery of the apparent region of dense viroplasm. Electron dense cores (short arrow) and free membrane fragments (double arrow) can be seen within the nucleus. TEM image, scale bar $=250 \mathrm{~nm}$

Clyde estuary may be compromised. Previous studies on the defence capability of Crangon crangon have shown that exposure to contaminated harbour dredge spoils led to a reduced total haemocyte count and blood cell phenoloxidase activity (Smith et al. 1995). It is conceivable that shrimp sampled from some estuarine locations may be similarly compromised and hence unable to mount an immune response to CcBVinfected tubule epithelial cells. Such interpretation is reinforced by previous studies on occluded baculovirus species that have indicated that environmental stressors can enhance the prevalence and severity of these infections. Crowding or exposure to sublethal amounts of PCBs increases the prevalence of Baculovirus penaeii in penaeid shrimps (Couch 1974, Couch \& Courtney 1977), while poor environmental conditions, shell disease, general bacterial infections and carapace fouling have been associated with an increased prevalence of Monodon baculovirus (MBV) in Penaeus monodon (Lightner et al. 1983). That stress has been found to exacerbate viral prevalence and disease in marine invertebrates is further reinforced by studies of vertebrate populations where it has been stated that '.. . the most important factor in transforming an infection into a disease is stress' (Overstreet 1978). In such a way, latent infections may transform to patent disease (Sindermann 1979) and even cause epizootics (Lightner \& Redman 1981). Johnson (1984) states that studies on the effects of stress on viral disease in marine invertebrates will prove invaluable to evaluate the effects of pollutants or other man-made stressors on natural populations and in aquaculture. The ubiquity of $C$. crangon in estuarine and coastal locations and the potential for epizootic CcBV in this 

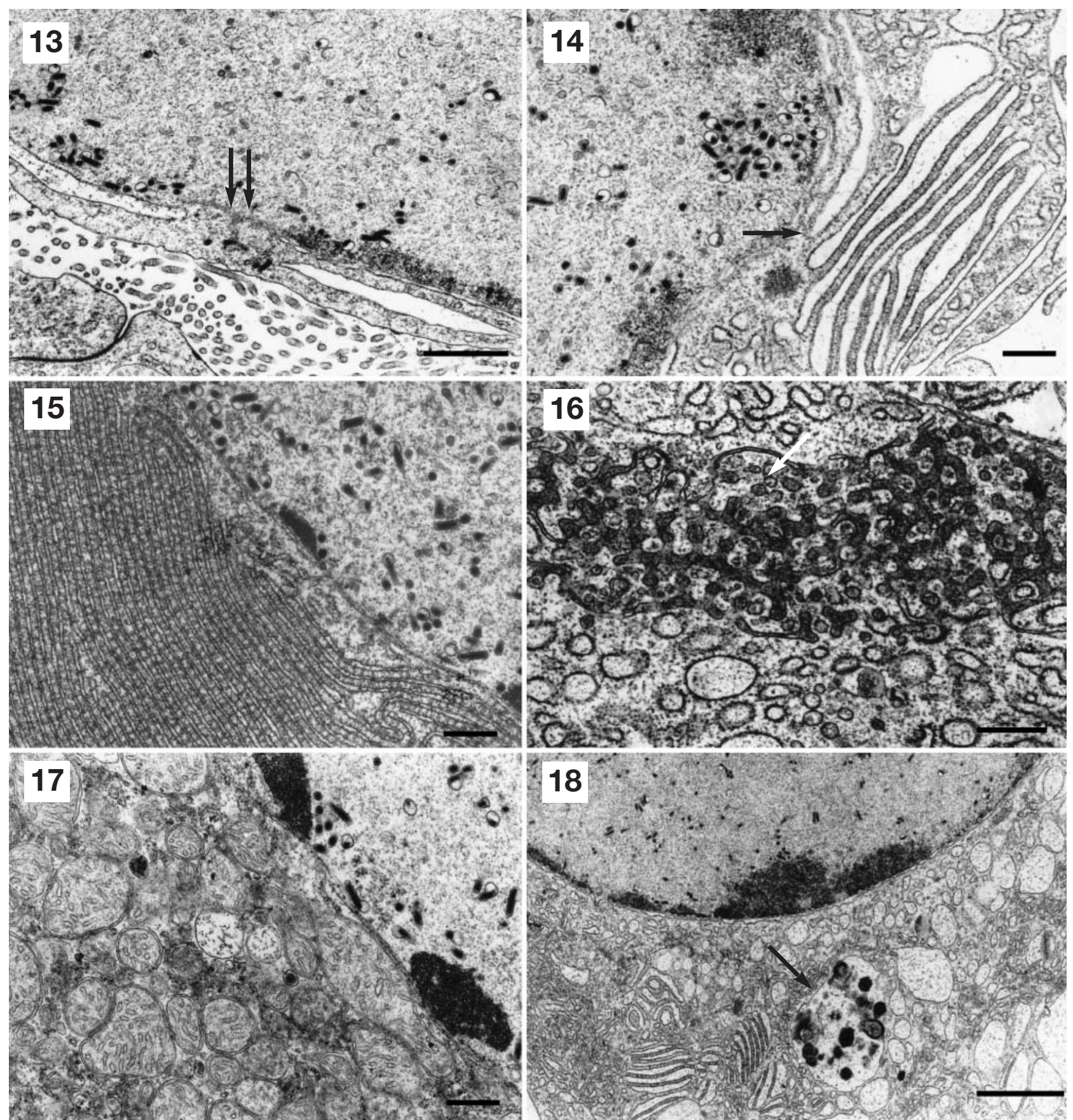

Figs. 13 to 18. Crangon crangon infected with C. crangon bacilliform virus (CcBV). Fig. 13. Sloughed hepatopancreatic epithelial cell with either a breach of the nuclear membrane (double arrow) or a nuclear pore. Note the presence of bacilliform virions in the cytoplasm (arrow). TEM image, scale bar $=1 \mu \mathrm{m}$. Fig. 14. Periphery of nucleus of a CcBV-infected cell showing a clear expansion of the outer nuclear membrane into a labyrinth of supposed endoplasmic reticulum (arrow). See also Figs. 15 \& 16 . TEM image, scale bar $=0.5 \mu \mathrm{m}$. Fig. 15. Periphery of $\mathrm{CcBV}$-infected nucleus showing massive proliferation of rough endoplasmic reticulum. Such expansions appeared to be initiated at the outer nuclear membrane (see Fig. 14). TEM image, scale bar $=0.5 \mu \mathrm{m}$ Fig. 16. Magnification of the cytoplasm of a CcBv-infected cell showing a labyrinthal proliferation of membranous material. Such expansions appeared to be associated with the production of discrete membrane-bound vesicles (arrow). Scale bar $=0.5 \mu \mathrm{m}$. Fig. 17. Opposite edge of same cell as in Fig. 15 showing an apparent proliferation of mitochondria. TEM image, scale bar = $0.5 \mu \mathrm{m}$. Fig. 18. Peri-nuclear region of CcBV-infected cell containing lysosomal aggregates (arrow) that were sometimes associated with the proliferated endoplasmic reticulum shown in Figs. 14, 15 \& 16. Under the light microscope, these regions appeared eosinophilic and were particularly apparent in cells sloughed into the hepatopancreatic tubule lumen (see Fig. 3). TEM image, 
species may provide an ideal disease model for future studies on the effect of stress and pollution on prevalence, pathogenesis and severity of disease. Furthermore, in addition to blood-cell-derived defence factors, it may also provide an ideal model for studying other antiviral substances in the haemolymph and tissues of crustaceans (Pan et al. 2000).

Crangon crangon supports an important fishery in Europe. The largest fishery for this species is located in the Wadden Sea (a nursery area for this species; del Norte-Campos \& Temming 1998). Fishing fleets from Germany, the Netherlands, Denmark and France are responsible for the majority of landings. Due to its occurrence in large populations and its role as both a predator and prey organism, it is a key species involved in cycling of the benthic habitat (Berghan 1996). The importance of C. crangon as a fishery product has necessitated attempts to estimate natural mortality rates in major fisheries. For the Wadden Sea fishery, stock mortality rate has been estimated at between 0.03 and $0.12 \mathrm{~d}^{-1}$ (del Norte-Campos \& Temming 1998). In this fishery, it has been stated that in addition to fishing mortality, environmental factors (such as salinity, depth and predator density) can affect the natural mortality rate. It is likely from the data presented in this paper that disease caused by the CcBV may also create an additional loading on natural mortality in C. crangon stocks. Significantly, C. crangon is also regarded as cannibalistic and it has been reported that cannibalism may contribute more than predation by other species towards natural mortality. As such, cannibalism may account for between 2 and $42 \%$ of mortalities in these fisheries (del Norte-Campos \& Temming 1998). Due to the presumption that CcBV is transmitted horizontally (as for other IBVs and the crustacean baculoviruses; Johnson 1984), it is tempting to suggest that cannibalism may also lead to the very high prevalence of $\mathrm{CcBV}$ infection in the C. crangon population from the Clyde estuary. However, the pathological manifestation of $\mathrm{CcBV}$ would also lead to liberation of infective stages (as loose virions and sloughed epithelial cells) in the faeces. Therefore, transmission may occur by coprophagy and benthic scavenging by $C$. crangon. Further studies are required to assess whether CcBV has the ability to affect recruitment in C. crangon fisheries and to whether this virus is specific to $C$. crangon or can infect other benthic crustacean species inhabiting these environments.

Acknowledgements. The authors would like to thank the crew of RV 'Endrick' (Scottish Environmental Protection Agency) for assistance with capture of shrimp and $\mathrm{Mr}$ Matthew Evans for histological preparation of material. The authors were supported by the Department of Environment, Food and Rural Affairs (Defra) under contract C1617.

\section{LITERATURE CITED}

Adams JR, McClintock JT (1991) Chapter 6: Baculoviridae: nuclear polyhedrosis viruses. Part 1. Nuclear polyhedrosis viruses of insects. In: Adams JR, Bonami JR (eds) Atlas of invertebrate viruses. CRC Press, Boca Raton, FL, p 87-204

Aguirre Guzmán G, Ascencio Valle F (2000) Infectious disease in shrimp species with aquaculture potential. Res Dev Microbiol 4:333-348

Anderson IG, Prior HC (1992) Baculovirus infections in mud crab, Scylla serrata, and a freshwater crayfish, Cherax quadricarinatus, from Australia. J Invertebr Pathol 60: 265-273

Berghan R (1996) Episodic mass invasions of juvenile gadoids into the Wadden Sea and their consequences for the population dynamics of brown shrimp (Crangon crangon). In: Dworschak PC, Stachowitsch M, Ott JA (eds) Influences of organisms on their environment: the role of episodic events. Blackwell Wissenschafts-Verlag, Berlin, p 251-260

Blissard G, Black B, Keddie BA, Possee R, Rohrmann G, Theilmann D, Volkman L (1999). Family Baculoviridae. In: van Regenmortel MHV, Bishop DHL, Carstens EM, Estes MK and 6 others (eds) Virus taxonomy. 7th Report of the International Committee on Taxonomy of Viruses. Academic Press, New York, p 195-202

Bonami JR, Lightner DV (1991) Unclassified viruses of Crustacea. In: Adams JR, Bonami JR (eds) Atlas of invertebrate viruses. CRC Press, Boca Raton, FL, p 597-622

Couch JA (1974) Free and occluded virus, similar to Baculovirus, in hepatopancreas of pink shrimp. Nature 247:229-231

Couch JA (1989) The membranous labyrinth in baculovirus-infected crustacean cells: possible roles in viral reproduction. Dis Aquat Org 7:39-53

Couch JA (1991) Chapter 6: Baculoviridae: nuclear polyhedrosis viruses. Part 2. Nuclear polyhedrosis viruses of invertebrates other than insects. In: Adams JR, Bonami JR (eds) Atlas of invertebrate viruses. CRC Press, Boca Raton, FL, p 205-226

Couch JA, Courtney L (1977) Interaction of chemical pollutants and virus in a crustacean: a novel bioassay system. Ann New York Acad Sci 298:497-504

del Norte-Campos AGC, Temming A (1998) Population dynamics of the brown shrimp Crangon crangon L., in shallow areas of the German Wadden Sea. Fish Manag Ecol 5:303-322

Edgerton B, Paasonen P, Henttonen P, Owens L (1996) Description of a bacilliform virus from the freshwater crayfish, Astacus astacus. J Invertebr Pathol 68:187-190

Edgerton BF, Webb R, Anderson IG, Kulpa EC (2000) Description of a presumptive hepatopancreatic reovirus, and a putative gill parvovirus, in the freshwater crayfish Cherax quadricarinatus. Dis Aquat Org 41:83-90

Edgerton BF, Watt H, Becheras JM, Bonami JR (2002) An intranuclear bacilliform virus associated with near extirpation of Austropotamobius pallipes Lereboullet from the Nant watershed in Ardéche, France. J Fish Dis 25:523-531

Evans LH, Edgerton BF (2002) Pathogens, parasites and commensals. In: Holdich DM (ed) Biology of freshwater crayfish. Blackwell Science, Oxford, p 377-438

Everett H, McFadden G (1999) Apoptosis: an innate immune response to virus infection. Trends Microbiol 167:160-165

Flegel TW (1997) Major viral diseases of the black tiger prawn (Penaeus monodon) in Thailand. World J Mirobiol Biotechnol 13:433-442

Groff JM, McDowell T, Friedman CS, Hedrick RP (1993) Detection of a nonoccluded bacoluvirus in the freshwater crayfish Cherax quadricarinatus in North America. J Aquat 
Anim Health 5:275-279

Hopwood D (1996) Fixation and fixatives. In: Bamcroft JD, Stevens A (eds) Theory and practice of histopathological techniques, 4th edn. Churchill Livingstone, Hong Kong, p 23-46

Huger AM, Krieg A (1991) Chapter 9: Baculoviridae: nonoccluded baculoviruses. In: Adams JR, Bonami JR (eds) Atlas of invertebrate viruses. CRC Press, Boca Raton, FL, p 287-319

ICES (2001) Report of the working group on Crangon fisheries and life history. Report No. CM 2001/G:10. Living Resources Committee, International Council for the Exploration of the Sea (ICES), Copenhagen

Johnson PT (1977) A viral disease of the blue crab, Callinectes sapidus: histopathology and differential diagnosis. J Invertebr Pathol 29:201-209

Johnson PT (1983) Diseases caused by viruses, rickettsia, bacteria, and fungi. In: Provenzano AJ Jr (ed) The biology of the Crustacea, Vol 6. Pathobiology. Academic Press, New York, p 1-78

Johnson PT (1984) Viral diseases of marine invertebrates. Helgol Meeresunters 37:65-98

Johnson PT, Lightner DV (1988) Rod-shaped nuclear viruses of crustaceans: gut-infecting species. Dis Aquat Org 5: 123-141

Lightner DV, Redman RM (1981) A baculovirus-caused disease of the penaeid shrimp, Penaeus monodon. J Invertebr Pathol 38:299-302

Lightner DV, Redman RM, Bell TA (1983) Observations on the geographic distribution, pathogenesis and morphology of the baculovirus from Penaeus monodon Fabricius. Aquaculture 32:209-233

Murphy FA, Fauquet CM, Bishop DHL, Ghabrial SA, Jarvis AW, Martelli GP, Mayo MA, Summers MD (1995) Virus taxonomy: classification and nomenclature of viruses: sixth report of the International Committee on Taxonomy of Viruses. Springer-Verlag, Vienna

Editorial responsibility: Timothy Flegel,

Bangkok, Thailand
Overstreet RM (1978) Marine maladies? Worms, germs and other symbionts from the northern Gulf of Mexico. Mississippi-Alabama Consortium, Ocean Springs, MI, p 1-140

Pan J, Kurovsky A, Xu B, Chopra AK, Coppenhaver DH, Singh IP, Braon S (2000) Broad antiviral activity in tissues of crustaceans. Antiviral Res 48:39-47

Pappalardo R, Mari J, Bonami JR (1986) $\tau$ (tau) virus infection of Carcinus mediterraneus: histology, cytopathology, and experimental transmission of the disease. J Invertebr Pathol 47:361-368

Reynolds ES (1963) The use of lead citrate at high $\mathrm{pH}$ as an electron-opaque stain in electron microscopy. J Cell Biol $17: 208-212$

Sano T, Nishimura T, Oguma K, Momoyama K, Takeno N (1981) Baculovirus infection of cultured Kuruma shrimp, Penaeus japonicus in Japan. Fish Pathol 15:185-191

Sano T, Nishimura T, Fukuda H, Hayashida T, Momoyama K (1984) Baculoviral mid-gut gland necrosis (BMN) of Kuruma shrimp (Penaeus japonicus) larvae in Japanese intensive culture systems. Helgol Meeresunters 37:255-264

Sindermann CJ (1979) Pollution-associated diseases and abnormalities of fish and shellfish: a review. Fish Bull 76: $717-749$

Smith VJ, Swindlehurst RJ, Johnston PA, Vethaak AD (1995) Disturbance of host defence capability in the common shrimp, Crangon crangon, by exposure to harbour dredge spoils. Aquat Toxicol 32:43-58

Tanada Y, Hess RT (1991) Chapter 7: Baculoviridae: granulosis viruses. In: Adams JR, Bonami JR (eds) Atlas of invertebrate viruses. CRC Press, Boca Raton, FL, p 227-257

Vago C (1966) A virus disease in Crustacea. Nature 209:1290

Vogt G (1996) Cytopathology of Bay of Piran shrimp virus (BPSV), a new crustacean virus from the Mediterranean Sea. J Invertebr Pathol 68:239-245

Walter U, Becker PH (1996) Occurrence and consumption of seabirds scavenging on shrimp trawler discards in the Wadden Sea. ICES J Mar Sci 54:684-694

Submitted: August 19; Accepted: October 31, 2003

Proofs received from author(s): February 9, 2004 